\title{
フラッシュ形エンドプレート接合形式を有する H 形断面梁の 崩壊挙動と横座屈耐力推定法 \\ FAILURES AND PREDICTION METHODS OF LATERAL BUCKLING STRENGTH OF H-SHAPED BEAMS CONNECTED BY FLUSH END PLATES
}

\author{
松原宏志*，高橋順一**，池口義治***，五十嵐 規矩夫****

\section{Hiroshi MATSUBARA, Junichi TAKAHASHI, Yoshiharu IKEGUCHI and Kikuo IKARASHI}

\begin{abstract}
In this paper, the experiment of the full scale specimen and the nonlinear FEM analysis have been conducted to obtain the behavior of $\mathrm{H}$-shaped beam connected by the flush end plates which fall into the connection failures or the lateral buckling. As a result, the intensities of restraint of the beam ends are reduced by the end plates deformation, and then the lateral buckling strengths of the beams are reduced by the deformation. We present the prediction methods of the lateral buckling strength of the beam influenced by the out of plane deformation of the flush end plates.
\end{abstract}

Keywords : Flush End Plate, H-shaped beam, Lateral Buckling Strength, Nonlinear FEM, Boundary Condition, Axial Force フラッシュ形エンドプレート, H 形断面梁, 横座屈耐力, 非線形有限要素解析, 境界条件, 軸力

\section{1. 序}

施工技能者数の減少により, 将来より簡易な接合工法のニーズが 高まることが予想される。ここで, 既往の簡易な接合工法の一つに, エンドプレート形式がある。この接合形式は, 現場の溶接レスを実 現し, かつスプリットティ形式のような現場での多数の高力ボルト の施工を必要としない。さらに, エンドプレート形式の中で, Fig.1 に示すフラッシュ形エンドプレート (Flush end plate) と呼ばれる, エンドプレートの高さと部材せいがほぼ同じとなる工法は, 拡張形 エンドプレート (Extended end plate) に比べ, 突出部分が小さく 運搬が容易である。また, 接合ボルトが部材の外に出ないため, 床 の施工も容易である。しかし, フラッシュ形エンドプレート形式は, エンドプレートの材料強度や板厚を極端に大きくしない限り, スプ リットティ形式や拡張形エンドプレートに比べ, 小さい曲げモーメ ントでエンドプレートが面外に塑性変形し, 梁フランジがパネルゾ ーン表面から離間する。そのため, 梁の横座屈に関して重要な指標 である境界条件としての拘束度が低下し, 他の 2 つの接合形式と同 一に扱うと危険側になる可能性があるが，この点に関する指針や既 往の研究はなく, 設計法があいまいなままとなっている。

エンドプレート形式の設計法に関しては, 文献 1)に記載があり, エンドプレートをスプリットティに置き換える設計法と, エンドプ レートを十分厚くして剛体として扱う設計法が記されている。しか

し，ここでは拡張形エンドプレートのみが対象とされ，フラッシュ 形エンドプレートに関する記載はない。

国内のフラッシュ形エンドプレート形式に関する研究として, 文 献 2）があり, 降伏線理論により, 接合部の降伏耐力及び最大耐力 の予測が可能とされている。他にも文献 3)では, 初期剛性の予測方 法が記載され, 文献 4)では, 繰り返しによるピンチングの発生等が 報告されている。文献 5)では, フラッシュ形エンドプレートを用い て, 接合ボルトを塑性化させる場合, 塑性変形能力が乏しいという 結果が得られている。海外の文献 6)には, フラッシュ形エンドプレ ートを含むエンドプレート形式の設計法が記載されている。ここで は, 接合部の塑性変形能力の分類方法が記載され，接合ボルトの耐 カが大きいほど, またエンドプレートの板厚が小さいほど, 変形能 力が大きいものとして分類される。

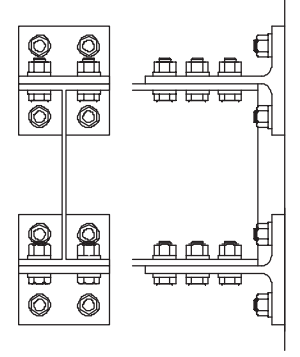

(a)T stub
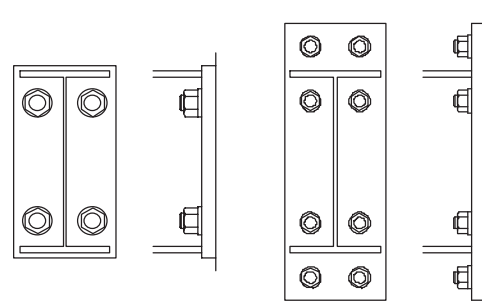

(b)Flush end plate (c)Extended end plate Fig.1 Connection examples

\footnotetext{
* 旭化成ホームズ侏) 工修

** 旭化成株生産技術本部生産技術センターC A E 技術部 博士 (工学)

*** 旭化成ホームズ侏) 博士(工学)

**** 東京工業大学環境・社会理工学院建築学系 准教授・博士 (工学)
}

Asahi Kasei Homes Corporation, M. Eng.

Asahi Kasei Corporation, Corporate Production Technology, Production Technology Center, Computer Aided Engineering Dept., Dr. Eng.

Asahi Kasei Homes Corporation, Dr. Eng.

Assoc. Prof., Dept. of Arch. and Build. Eng., Tokyo Institute of Technology, Dr. Eng. 
一方，横座屈に関しては，文献 7)により各種境界条件とモーメン 卜勾配による弾性横座屈耐力に与える影響がエネルギー法により導 かれ, 設計式としてまとめられている。また, 文献 8) で局部座屈と 横座屈の連成を考慮した評価指標により変形能力を予測する方法が 示され，ここでは梁の境界条件が考慮されている。

このように, 梁の横座屈を考慮した耐力及び変形能力を決める上 で重要な端部境界条件に関する研究が存在する中, フラッシュ形エ ンドプレートと横座屈を関連付けた研究は, 国内及び海外において 見当たらない。そこで本研究では, フラッシュ形エンドプレート接 合形式を有する $\mathrm{H}$ 形断面梁の崩壊挙動を調査し, 横座屈を考慮した 最大耐力の推定方法を提案することを目的とする。なお今回，局部 座屈については，検討対象外とする。

\section{2. フラッシュ形エンドプレートにより接合される H 形断面梁の梁 端の崩壊挙動}

横座屈を伴わない実大実験及び FEM 解析より，フラッシュ形エ ンドプレートにより接合される $\mathrm{H}$ 形断面梁の崩壊形式, 最大耐力, 及びエンドプレートの面外変形状態の推定方法を検討する。

\section{1 フラッシュ形エンドプレート及び梁の崩壊挙動と最大耐カ}

まず,フラッシュ形エンドプレートにより接合される H 形断面梁 の接合部近傍を，実大卜の字形曲げせん断実験により崩壊させる。 実験は，断面が H-250×125×6×9 の H 形断面梁と， ロ- $150 \times 150 \times 22$ の柱を Fig.2 に示す通り接合し，柱の両端をピン支持し， H 形断面 梁の先端を強制変位させる。柱と梁は，柱に設けたタップ孔にエン ドプレートを介して 6 本の M20 の特殊トルシア形高力ボルト (S10T)を片側から締めこむことにより接合した。なお，本ボルトに は頭がなく, 柱のタップ孔及びボルトの柱に締めこむ側には逆ねじ が切られており，施工時はボルトの軸を左回転しながら締めこみつ つ，その反力でナットを右回転することにより，ボルトに初期張力 が導入される。接合部の詳細を Fig. 3 に, 素材引張試験より得られ た材料特性を Table1 に示す。載荷プログラムは Fig.4 に示す通り, 変位制御の正負交番繰り返し載荷とした。なお，Fig.3 に示す通り， ボルトは 3 段配置し 2 段目のボルトが梁心からずれているが, 後述 の試験結果 Fig.5 に示す通り, 正負の最大耐力がほぼ変わらないこ とから，本実験では，この２段目のボルト位置が破壊性状に与えた 影響は小さいと考えている。変位の計測位置は, Fig.2 に示す通り， 全体の変形を計測する $D 1 \sim 3$, 柱の部材角を測定する $D 4,5$, 及びエ ンドプレートの面外変形量を測定する $D 6,7$ とし, 梁端部には Fig.2 右下に示す通り，フランジにひずみゲージを貼付した。ここで、後 述の Table2 に示す通り，柱フランジの面外変形（mode1）による耐 力はエンドプレートの面外変形 $(\operatorname{mode} 2)$ による耐力の 8 倍程度あり, 本実験における柱フランジの面外変形量は, エンドプレートの面外 変形量に比べ小さいと考えられるため, $D 6,7$ をエンドプレートの面 外変形量として扱うこととした。

Fig.5 に本実験より得られた梁端部の曲げモーメント $M$ と梁の部 材角 $\theta_{b}$ の関係, Fig.6に $M$ とフランジに貼付したひずみゲージの值 $E 1 \sim E 4$ の平均值及び $E 5 \sim E 8$ の平均值の関係, Fig.7 に $M$ とエンド プレートの面外変形量 $D 6$ 及び $D 7$ の関係を示す。図の縦軸は素材試 験結果より算出した梁の全塑性曲げ耐力 $M p_{b}$ により無次元化してい る。 $M$ と $\theta_{b}$ は次に示す式(2.1), (2.2)により算出した。
Table1 Material properties

\begin{tabular}{|c|c|c|c|c|c|}
\hline \multicolumn{2}{|c|}{ section } & $\sigma_{y}$ & $\sigma_{u}$ & $\varepsilon_{u}$ & $E$ \\
\hline \multicolumn{2}{|c|}{$\square-150 \times 150 \times 22$} & 350 & 531 & 29 & $2.04 \times 10^{5}$ \\
\hline \multirow{2}{*}{$\begin{array}{c}\mathrm{H}-250 \times 125 \\
\times 6 \times 9\end{array}$} & flange & 295 & 453 & 44 & $2.03 \times 10^{5}$ \\
\cline { 2 - 6 } & web & 293 & 442 & 43 & $2.08 \times 10^{5}$ \\
\cline { 2 - 7 } & endplate & 284 & 463 & 49 & $2.07 \times 10^{5}$ \\
\hline
\end{tabular}

$\sigma_{y}:$ yield strength $\left[\mathrm{N} / \mathrm{mm}^{2}\right]$

$\sigma_{u}:$ ultimate strength $\left[\mathrm{N} / \mathrm{mm}^{2}\right]$

$\varepsilon_{u}$ : elongation[\%]

$E$ : young's modulus[N/ $\left./ \mathrm{mm}^{2}\right]$

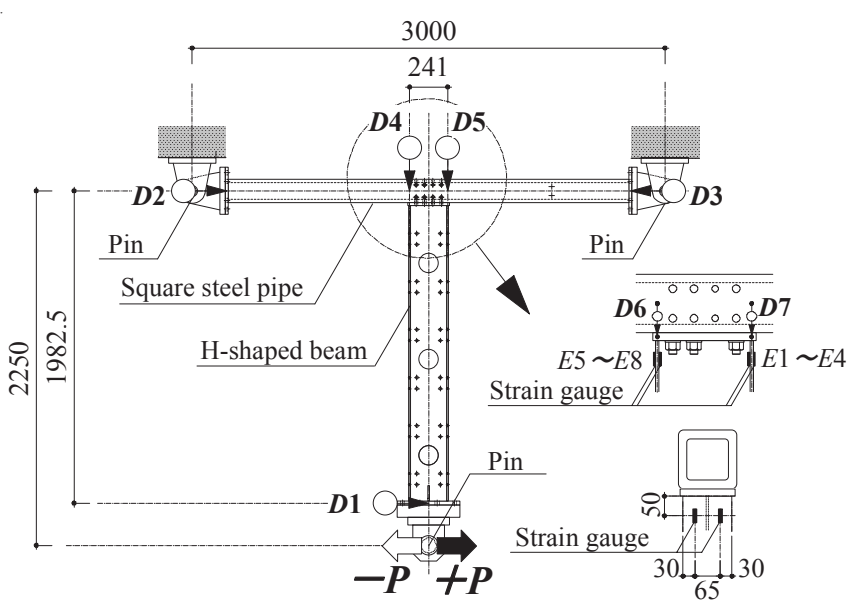

Fig.2 Specimen

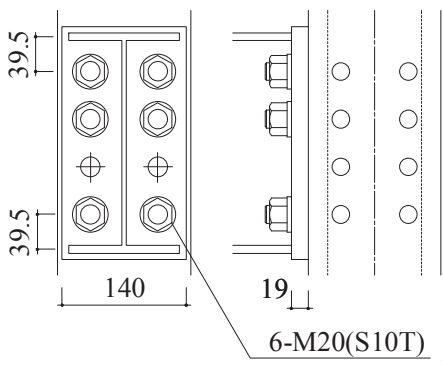

Fig.3 Detail of the connection

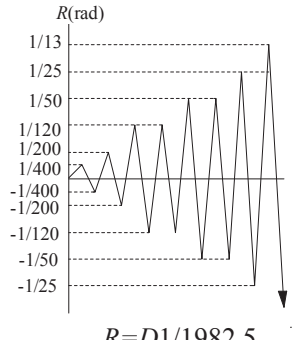

$R=D 1 / 1982.5$

Fig.4 Loading schedule

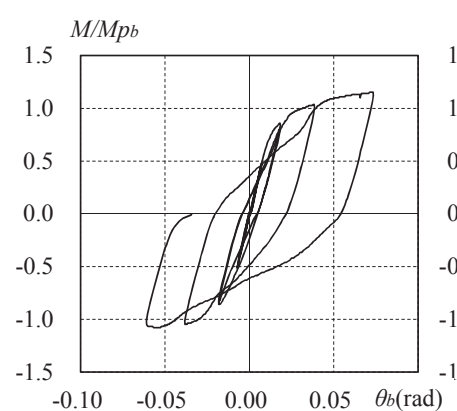

Fig. $5 \mathrm{M}-\theta_{b}$ relationship

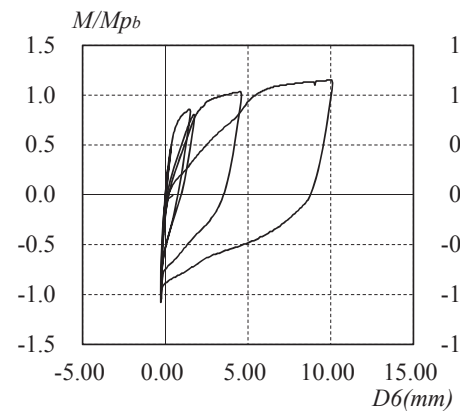

(a)

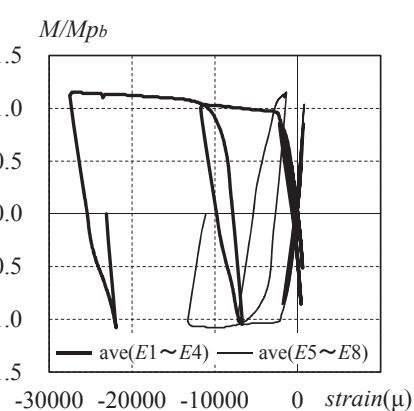

Fig.6 Flange strain

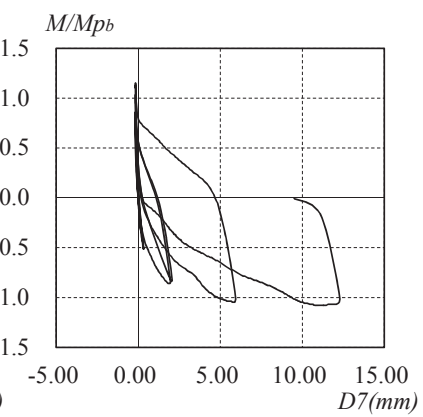

(b)
Fig.7 End plate deformation 
$M=P \times(2250-75)$

$\theta_{b}=\frac{\left\{D 1-\frac{(D 2-D 3)}{2}\right\}}{1982.5}-\frac{D 4-D 5}{241}$

ここで, $P, D 1 〜 D 5$ は Fig.2 に示すジャッキロードセルによる荷重, 変位計による計測值である。

Fig.5 に示す通り, H 形断面梁の耐力は, ピンチングを示しながら, 素材試験結果より算出した梁の全塑性曲げ而力 $M p_{b}$ を超えるまで上 昇している。しかし, Fig.6のひずみゲージの值は， $M$ が正の時圧縮 フランジ $(E 1 \sim E 4)$ が降伏し, 引張フランジ $(E 5 \sim E 8)$ は弾性, $M$ が 負の時も圧縮側フランジ $(E 5 \sim E 8)$ のみが圧縮降伏し, 引張フランジ $(E 1 \sim E 4)$ は弾性であることを示している。これは, Fig.7 に示すよ うに，引張側のエンドプレートが面外変形することにより，引張フ ランジの応力負担が小さくなり, 引張フランジ直下のボルト高さ位 置近傍でウェブが大きな応力を負担しているため, 引張フランジが 降伏しないためである。この崩壊形式を図示すると, Fig.8 となる2)。 文献 2) を参考にすると, 接合部の崩壊形式は 4 つ考えられる。梁が 取りつく柱フランジの面外変形 (mode1), Fig.8 に示すエンドプレ 一トの面外曲げと梁ウェブの母材の塑性化の組み合わせ（mode2）, エンドプレートのみが面外変形しウェブが弾性を保つ崩壊 (mode3), ボルトの破断（mode4）である。それぞれの崩壊形式に 対応した耐力算出式が提案されており, 最も耐力が小さいものが真 の崩壊形式となる。本実験の最大耐力を文献 2)に記載された方法に より推定すると, Table2 のようになる。Table2 より, 本実験の崩壊 形式は mode 2 で, 最大耐力の推定值は, 実験による最大耐力 ${ }_{e}$ max とほぼ一致する。ただし, mode2 の場合の降伏線位置は，引張側フ ランジから最も近いボルト孔の縁までの距離とした。ここで, mode 2 の耐力の算出式を以下に示す。導出過程は文献 2) を参照さ れたい。

$$
\begin{gathered}
M p_{j}=\left(B_{f} t_{f}{ }^{2} \sigma_{y f}+B_{e} t_{e}{ }^{2} \sigma_{y e}+h_{1} h_{2} t_{w} \sigma_{y w}\right) h /\left(2 h_{2}\right) \\
M u_{j}=\left(B_{f} t_{f}{ }^{2} \sigma_{u f}+B_{e} t_{e}{ }^{2} \sigma_{u e}+h_{1} h_{2} t_{w} \sigma_{u w}\right) h /\left(2 h_{2}\right)
\end{gathered}
$$

ここで, $\sigma_{y f}, \sigma_{u f}$ はフランジの降伏応力, 引張強さ， $\sigma_{y w}, \sigma_{u w}$ はウ エブの降伏応力, 引張強さ, $\sigma_{y e}, \sigma_{u e}$ はエンドプレートの降伏応力, 引張強さ, $M p_{j}$ は接合部の降伏耐力, $M u_{j}$ は接合部の最大耐力である。

本研究は mode2 で崩壊するもののみを対象としており, その理 由として, 柱フランジが面外変形する mode1 は柱の崩壊を招く懸 念があること, エンドプレートが極端に薄く梁ウェブが塑性化しな い mode3 は, 文献 2) で非現実的とされていること, ボルトが破断 する mode4 は文献 5)，6）で塑性変形能力がそしいとされているた めである。

次に, 実験により得られた梁端部の曲げモーメント $M$ とエンドプ レートの面外変形による梁の回転角 $\theta_{\text {plate }}$ の関係を Fig.9に, $M$ と梁 自体の変形 $\theta_{\text {beam }}$ の関係を Fig.10に示す。ここで $\theta_{\text {plate }}, \theta_{\text {beam }}$ は以下 の式(2.5), (2.6)により算出している。

$$
\begin{aligned}
& \theta_{\text {plate }}=(D 6-D 7) / 241 \\
& \theta_{\text {beam }}=\theta_{b}-\theta_{\text {plate }}
\end{aligned}
$$

Fig.9 を見ると, $M-\theta_{\text {plate }}$ 関係は接合部の降伏耐力 $M p_{j}$ 付近で折れ曲 がり, 最大耐力 $M u_{j}$ でほぼ一定值となっており, 式(2.3) (2.4)の降伏 耐力及び最大耐力の推定式は妥当であると考えられる。また, Fig.10

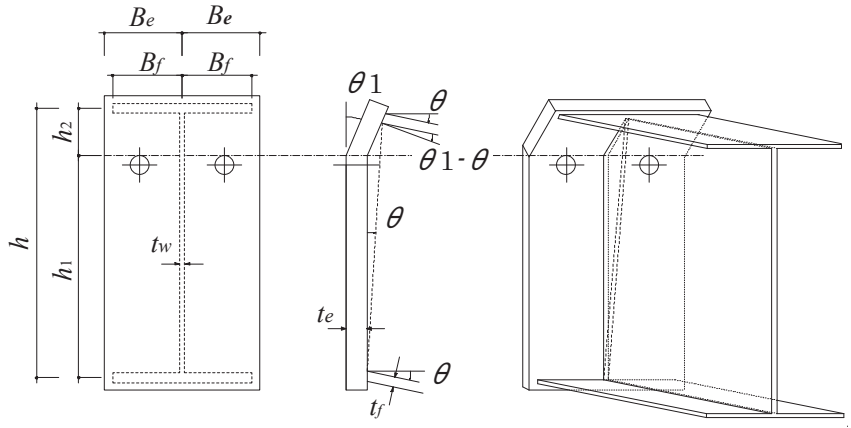

Fig.8 Failure mode2

Table2 Bending strength of the joint -theoretical

\begin{tabular}{|c|c|c|c|c|}
\hline Failure mode & 1 & 2 & 3 & 4 \\
\hline Theoretical strength $\left(\mathrm{Mu}_{j} / \mathrm{Mp}_{b}\right)$ & 8.92 & 1.17 & 2.51 & 1.78 \\
\hline Theoretical minimum strength & \multicolumn{5}{|c|}{1.17} \\
\hline Experimental maximum strength $\left({ }_{e} \max \right)$ & \multicolumn{5}{|c|}{15} \\
\hline
\end{tabular}

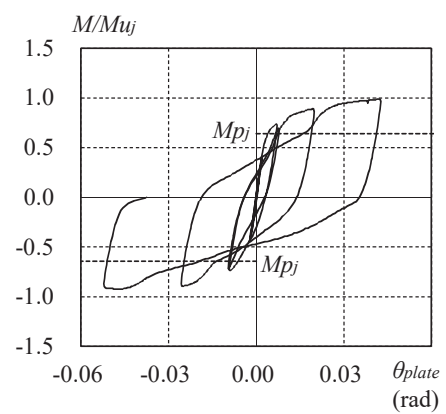

Fig. $9 M-\theta_{\text {plate }}$ relationship

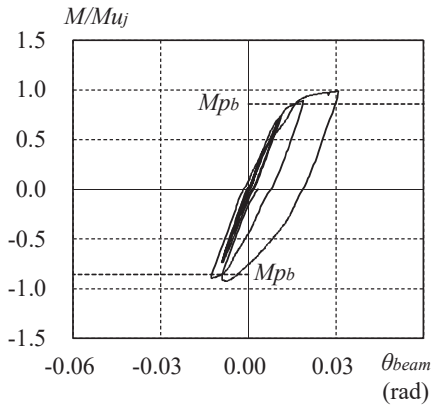

Fig.10 $M-\theta_{\text {beam }}$ relationship

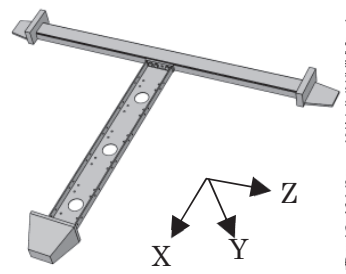

(a)Over view

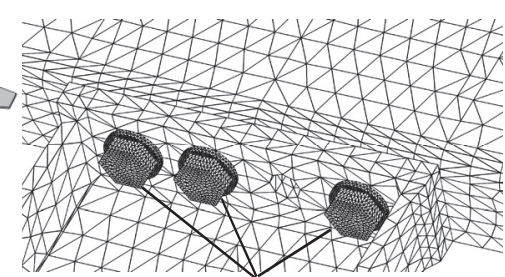

Bolts and Washers (b)Connection detail
Fig. 11 FEM model

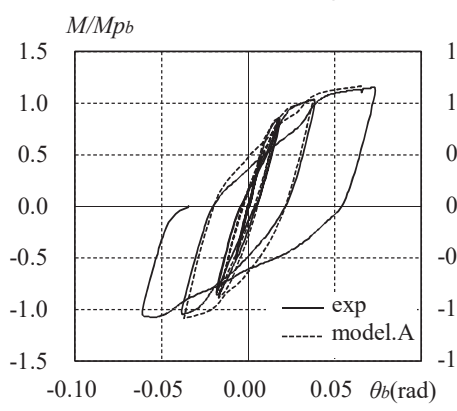

Fig.12 $M-\theta_{\text {plate }}$ relationship

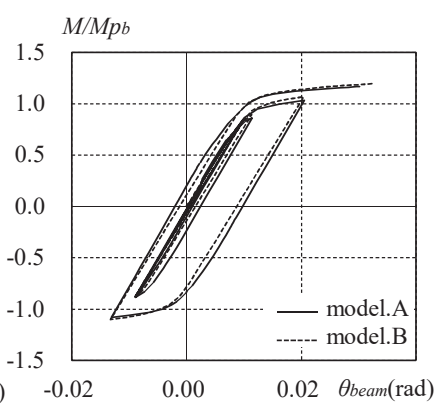

Fig.13 $M-\theta_{\text {beam }}$ relationship
を見ると梁は $M p_{b}$ を超えた後で塑性変形が進行し，剛接合された $\mathrm{H}$ 形断面梁の荷重変形関係と同様に見える。そのため, Fig.6に示す通 り接合部近傍では梁は圧縮フランジのみ降伏し, 引張フランジはほ ぼ弾性で中立軸位置が圧縮フランジ側に移動するが，梁自体の荷重 変形関係はこの影響を受けていないと思われる。

この予測を検証するために FEM 解析を実施する。FEM 解析に用 いるプログラムは ABAQUS6.14-2 とし, Fig.11 に示す通り前述の 実験をモデル化した。要素は 4 面体 2 次要素を用い, 境界条件は, 
対称面（X-Z 面）で分割し, 対称面の節点を $\mathrm{Y}$ 方向並進拘束した。 治具は剛体として扱うこととし，十分大きな弾性係数を与えた。ナ ットとボルトは一体化し, ボルトのナットからの出は省略した。ナ ット部分と座金は一体化し, 接触を考慮しない。柱とエンドプレー 卜間，及び座金とエンドプレート間は接触を考慮する。高力ボルト には初期張力として設計ボルト張力を与えた。応力ーひずみ関係は, 引張試験結果より得られた真応力一真ひずみ関係とし, ひずみ硬化 則は等方硬化とした。

解析のモデルは, 実験と同条件の model.A と, 接合部が塑性変形 しないようにエンドプレートを柱に固着した model.B とする。 model.A と実験結果の比較を Fig.12 に示す。Fig.12より, 曲げモー メントと部材角関係の FEM 解析と実験の対応は良い。

また, $M$ と式(2.5)による接合部の回転を除いた $\mathrm{H}$ 形断面梁自体の 変形 $\theta_{\text {beam }}$ の関係について model.A と model.B の比較を Fig.13 に示 す。両モデルの履歴はほぼ一致している。この結果より, フラッシ ユ形エンドプレートにより接合された $\mathrm{H}$ 形断面梁自体の荷重変形関 係は柱に完全に固定した場合とほぼ一致し, Fig.6に示した接合部近 傍の複雑なひず夕分布の影響を受けないことがわかった。つまり， 横座屈耐力を考える際に, 既往の研究により剛接合を対象に整理さ れている一般化細長比と座屈耐力の関係 9)を用いることができる可 能性がある。また，エンドプレートの面外変形と $\mathrm{H}$ 形断面梁の塑性 変形がともに発生する場合でも, それぞれの荷重変形関係は分離し て扱うことが可能であり, 接合部と梁の荷重変形関係が事前にわか っていれば，それらを直列で繋ぎ，接合部を含めた梁全体の荷重変 形関係を得ることもできると考えられる。ひずみ分布の影響に関し て, 同様の考察が文献 3)にもあり, ここではフラッシュ形エンドプ レートの面外変形により, 接合部近傍のひずみ分布が乱れるが, そ の領域は局所的であり, 梁自体の弾性剛性には影響しないと述べら れている。

以上, 接合部の最大耐力は式(2.4)により推定できることがわかっ た。また, エンドプレートの面外変形により接合部近傍では複雑な ひずみ分布となるが梁自体の荷重変形関係はその影響を受けず, 剛 接合されたものとして扱うことができることを示した。

\section{2 エンドプレートの離間状態の予測方法}

梁の横座屈に対する境界条件を考える上で, エンドプレートの柱 からの離間の有無が重要であると考えている。そこで, Fig.14 に示 すような正負交番漸増繰り返し荷重を受けるエンドプレートの挙動 を予測する方法について検討する。Fig.14 に示す通り, フラッシュ 形エンドプレートは, 梁フランジに生ずる引張力により, ある曲げ モーメントで面外に塑性変形し始め $(\mathrm{A} \sim \mathrm{B})$, 各サイクルにおける曲 げモーメントのピーク時に柱フランジ表面から最も大きく離間する (B 点)。その後, 曲げモーメントの低下により梁フランジに生じて いる引張力が低下すると, エンドプレートは逆向きに弾性除荷され $(\mathrm{B} \sim \mathrm{C})$, 続いて負側の曲げモーメントにより圧縮から引張に転じた 側は離間し始め, 同時に B 点で離間していた側は梁フランジに生ず る圧縮力により，徐々に柱に近づく方向に塑性変形し柱に接触する $(\mathrm{C} \sim \mathrm{D})$ 。柱に接触した圧縮側エンドプレートは，接触したまま耐力 を上昇させ, 再度ピークを迎える $(\mathrm{D} \sim \mathrm{E})$ 。再び曲げモーメントが除 荷されると, フランジに生じている圧縮力が減少し弾性除荷され $(\mathrm{E}$ 〜 F), 正側の曲げモーメントにより引張に転じた側は離間する $(\mathrm{F} \sim$
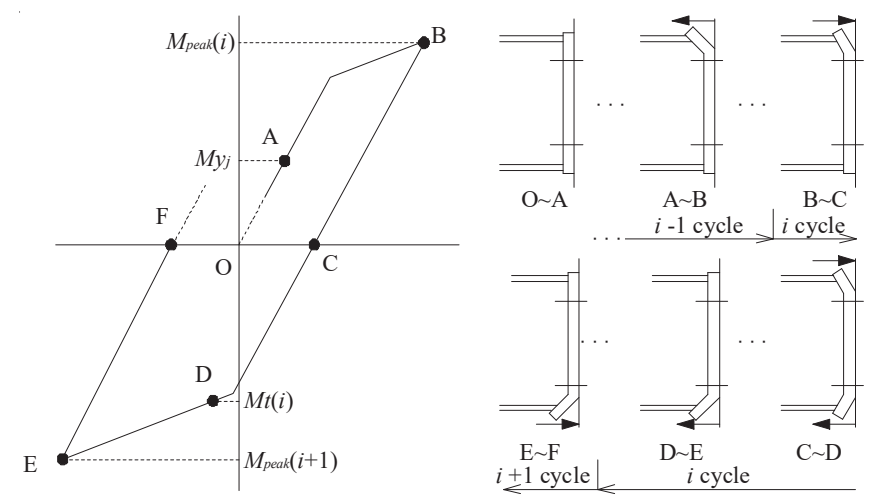

Fig.14 End plate contact $-M$ relationship

)。梁の上下フランジ側どちらも梁フランジに生ずる圧縮, 引張力に よりエンドプレートが徐々に塑性変形をするため, エンドプレート は曲げモーメントの正負が切り替わる瞬間から，一度離間した片側 がフランジに生ずる圧縮力により接触するまでの間 $(\mathrm{C} \sim \mathrm{D})$ は, 上下 フランジの両方が柱から離間している状態となる。また, 両側が離 間しているタイミング以外は片側が接触している状態となる。ここ で, エンドプレートが面外に塑性変形し始める初期降伏耐力を $M y_{j}$, 各サイクルのピーク值を $M_{\text {peak }}(n)$, さらに $M_{\text {peak }}(n)$ で離間していたエ ンドプレートが, 反対向きの曲げモーメントにより柱に接触する時 の曲げモーメントを $M t(n)$ と表記する。 $n$ は半サイクル数を示し, ピ ーク荷重から次のピーク荷重までを 1 サイクルとしている。以下に, $M_{\text {peak }}(n)$ と $M t(n)$ の関係を予測する方法を示す。

始めに, $M y_{j}$ の定義より, $\left|M_{\text {peak }}(m)\right|=\max \left(\left|M_{\text {peak }}(1)\right|,\left|M_{\text {peak }}(2)\right|\right.$, $\left.\cdots,\left|M_{\text {peak }}(n)\right|, \cdots\right) \leqq M y_{j}$ ならばエンドプレートは弾性範囲であり，除荷 されると柱フランジに接触するため, $|M t(m)|=0$ と予測できる。そこ で，次の仮定を設け， $M y_{j}$ を求める。

接合部が $M y_{j}$ を負担する場合, 次の 2 か所に曲げヒンジが生ずる ものとする。

(1)梁 : Fig.15(a)に示す A-A 断面でエンドプレートに接する位置 (2)エンドプレート：引張フランジに最も近いボルト孔の縁の位置 (引張フランジ心からの距離を $h_{2}$ とする。)

以上の仮定により，Myj は式(2.7)により求められる。

$$
M y_{j}=\frac{\left\{M p_{(A-A)}+M p_{(B-B)}\right\} h}{h_{2}}
$$

ここで, $M p_{(A-A)}, \quad M p_{(B-B)}$ はそれぞれ(1)，(2)部の全塑性曲げモーメン トである。

次に, $\quad M_{\text {peak }}(l)=\max \left(\left|M_{\text {peak }}(1)\right|,\left|M_{\text {peak }}(2)\right|, \cdots,\left|M_{\text {peak }}(n)\right|, \cdots\right)>M y_{j}$ の場合 の $M_{\text {peak }}(l)$ と $M t(l)$ の関係を予測する。ここまでに，接合部の最大耐 力 $M u_{j}$ は式(2.4)により, 接合部の初期降伏耐力 $M y_{j}$ は式(2.7)により 求められることを示した。しかし，これらの情報だけでは $M t(l)$ を予 測することは困難である。そこで始めに，概略的な傾向と， $M_{\text {peak }}(l)$ が $M u_{j}$ の場合の $M t(l)$ を予測することを試みる。そのために，次の 5 つの仮定を設ける。

1 つ目は, Fig.15(b), (c)に示す通り, 接合部の応力中心位置を仮 定する。 2 目は，応力中心位置に力 $F$ を仮定する。 3 つ目は，1つ 目の応力中心間距離と， 2 つ目の $F$ の積が接合部に生ずる曲げモー メントであるとする。 4 つ目は, $M_{\text {peak }}(l)$ を求める時は, 片側接触し ている場合の応力中心間距離を適用し, $M t(l)$ に対しては両側離間し 

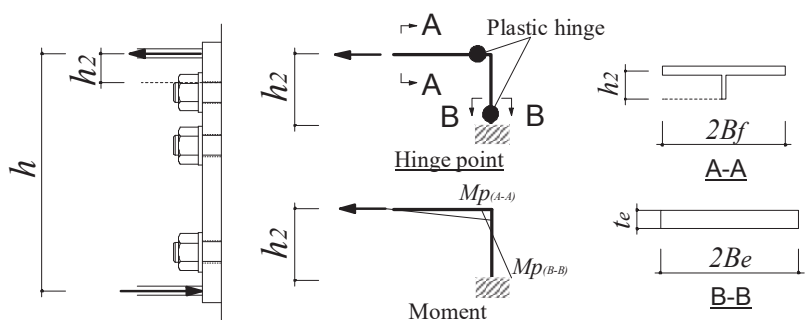

(a) Initial yield
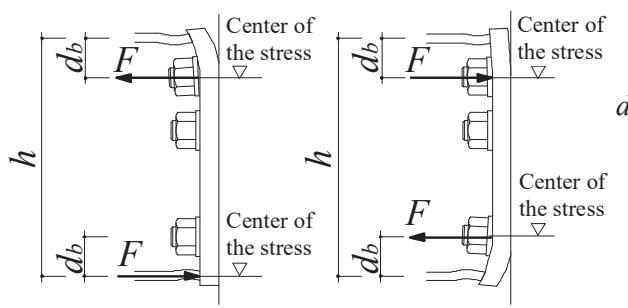

$d_{b}:$ Distance from the center of the beam fange to the bolts

\section{$\begin{array}{ll}\text { (b) Other side contact } & \text { (c) Both sides no contact }\end{array}$}

Fig.15 Definition of resistance

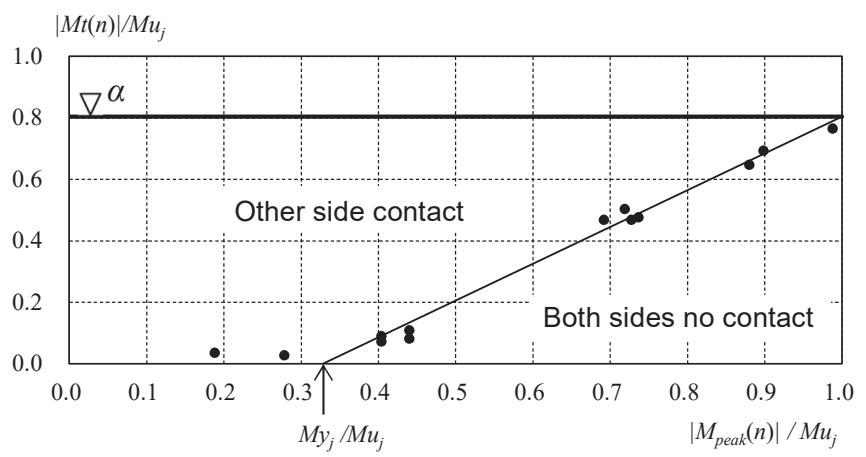

Fig.16 End plate contact condition

ている場合を適用する。 5 つ目は，2 つ目で定義した $F$ について次 の 2 つを仮定する。「Fが大きいほど，そこで離間したエンドプレー 卜を接触させるために必要な反対向きの $F$ は大きくなる」,「Fが最 大耐力に達した後, そこで離間したエンドプレートを接触させるた めに必要な反対向きの $F$ は, その最大耐力と同じ值である」。上の 5 つの仮定より，次のことが求められる。

$\left|M_{\text {peak }}(l)\right|$ が大きいほど, $|M t(l)|$ が大きくなる。また, $\left|M_{\text {peak }}(l)\right|$ が $M u_{j}$ の場合, 式(2.8)で示す $\alpha$ を用いて, $|M t(l)|$ は $\alpha M u_{j}$ と表現できると仮 定する。

$$
\alpha=\left(h-2 d_{b}\right) /\left(h-d_{b}\right)
$$

最後に，より詳細な $M_{\text {peak }}(n)$ と $M t(n)$ の関係を得るために，2.1 節 の実験結果を考察する。Fig.16 に, $M_{\text {peak }}(n)$ と $M t(n)$ の関係を $M u_{j}$ によ り無次元化して示す。図の横軸と縦軸は $M_{p e a k}(n)$ と $M t(n)$ の絶対值と している。なお, $M t(n)$ は Fig.7 の横軸のエンドプレートの開き量が 0 となる時の縦軸の曲げモーメントの值である。Fig.16 を見ると, $|M t(n)|$ は, $\left|M_{\text {peak }}(n)\right|=M y_{j}$ から増加し, $\left|M_{\text {peak }}(n)\right|=M u_{j}$ の場合, $\alpha M u_{j}$ と なる。前述の予想通りの結果が得られるとともに, $\left|M_{\text {peak }}(n)\right|$ と $|M t(n)|$ は, $\left|M_{\text {peak }}(n)\right|=M y_{j},|M t(n)|=0$ の点と $\left|M_{\text {peak }}(n)\right|=M u_{j},|M t(n)|=\alpha M u_{j}$ の 2 点 を結ぶ直線上にあるという新たな特徴が明らかになった。

本論では，接合部に生ずる曲げモーメントが，この直線よりも右 下にある場合は，エンドプレートは上下フランジ側ともに柱から離 間しているとし，左上にある場合は，片方のフランジ側が離間して いるとする。このエンドプレートの接触と曲げモーメントの関係が，

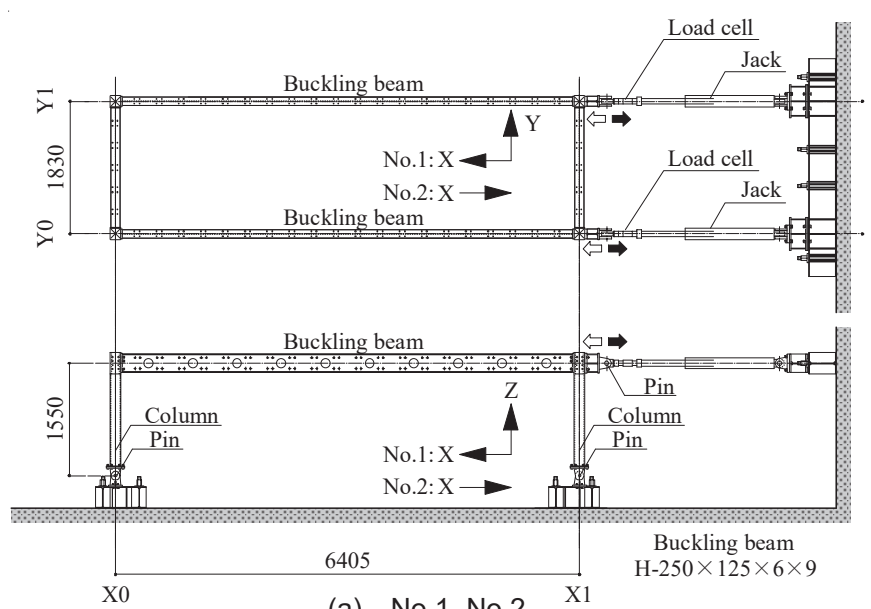

(a) No.1, No.2
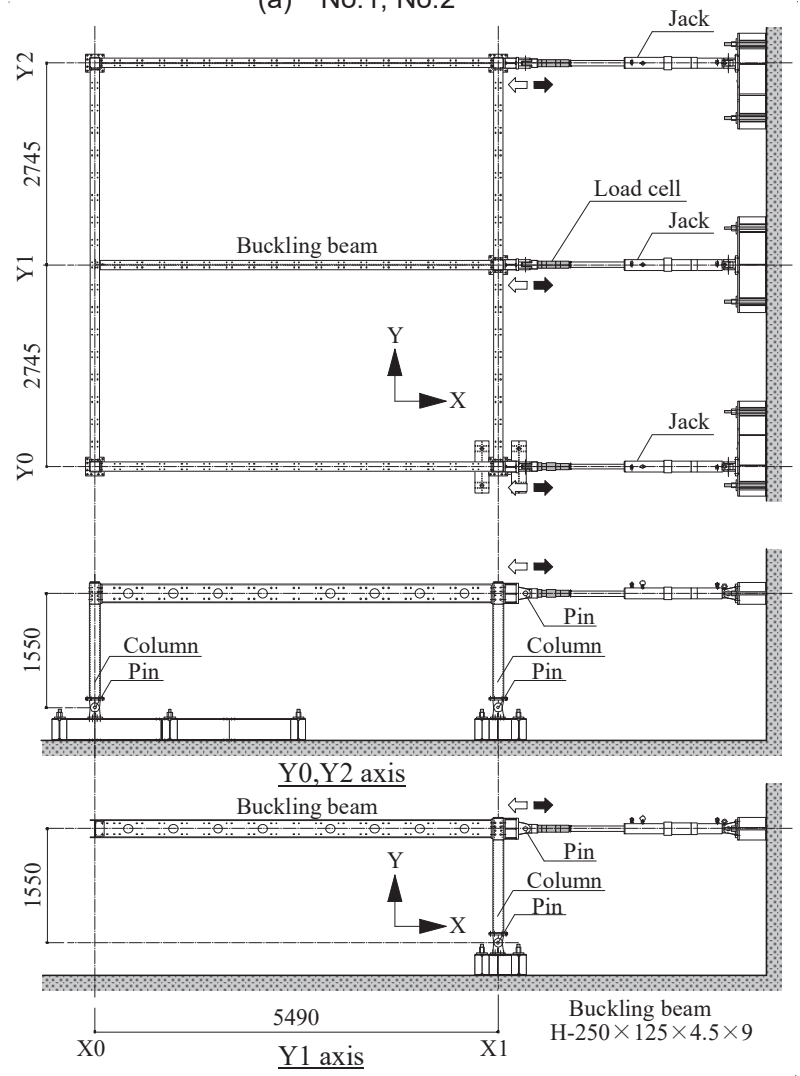

(b) No.3

Fig. 17 Specimen

載荷履歴を変化させても同じであるかの検証は，今後の課題とした い。

\section{3. フラッシュ形エンドプレートにより接合された H 形断面梁の横} 座屈性状

フラッシュ形エンドプレートによる横座屈に対する $\mathrm{H}$ 形断面梁 の境界条件を検討する実験及び FEM 解析を行った。

\section{1 実験によるH 形断面梁端部の境界条件の確認}

試験は全て実大フレームの中で H 形断面梁を座屈させるものであ る。荷重条件は, 梁に逆対称曲げと片端曲げを与える 2 種類とし, 逆対称曲げについては，H 形断面梁に圧縮軸力が入る状態で横座屈 するNo.1 と引張軸力が入る状態で横座屈するNo.2 とした。片端曲 げは，軸力が入らない No.3 のみとした。試験体の構成は Fig.17 に 示寸通り, 柱と $\mathrm{H}$ 形断面梁により構成された架構の柱頭をジャッキ 
により強制変位を与えることにより, 梁に曲げモーメントを与える。 No.3 は Y1 軸の梁を対象とし, この梁に軸力が入らない理由は, X0 軸の梁の弱軸曲げ剛性が小さいからである。実際に生じた軸力は, 梁に貼付したひずみゲージより, 最大耐力までNo.1 及びNo.2では ジャッキによる荷重の約半分が梁の軸力となり, No.3 では梁の軸力 は生じていないことを確認した。

梁に軸力を入れている理由は，軸力による接合部の固定度への影 響を観察するためと, 実際の構造物では, Fig.18 に示すように質量 と柱の配置位置により, 地震時において, 逆対称曲げとなる梁に軸 力が入る場合が想定されるためである。

梁断面及び柱梁接合部の詳細は，前述の実大卜の字形実験の接合 部と同じとし, 柱頭部に設けた厚み $22 \mathrm{~mm}$ の角形鋼管の下に厚み $9 \mathrm{~mm}$ の角形鋼管を溶接接合し柱を構成している。No.3 試験体の X0-Y1

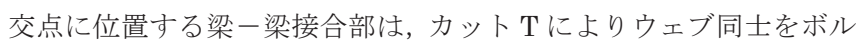
ト接合している。載荷スケジュールは, Fig.19 に示す変位制御の正 負交番繰り返し載荷（縦軸は，柱頭の X 方向水平変位 $\delta$ を $1550 \mathrm{~mm}$ で除した変形角）とし，全てのジャッキを同一変位で制御する。No.1 試験体はジャッキにより柱頭を押す方向を正とし, No.2, 3 は引く方 向を正とする。変位計測については, ジャッキ位置の水平変位, 及 び梁の横方向変位を計測した。梁の横方向変位の計測方法は, フラ ンジに固定した変位計により, 床から立ち上げた固定面に向かう距 離を計測した。座屈させる梁の材料特性をTable3 に示す。

実験により得られた, 梁端の曲げモーメント $M$ と変位 $\delta$ の関係を Fig.20 に示す。No.1 及びNo.2 の梁端の曲げモーメントは, 梁両端 の曲げモーメントが等しいと仮定し求めている。また, 縦軸は素材 試験結果に基づく梁の全塑性曲げ耐力 $M p_{b}$ により無次元化し, 接合 部の最大耐力 $M u_{j}$ を実線により示している。Fig.20より, No.1の $\mathrm{Y} 0, \mathrm{Y} 1$ 構面, No.2 の Y0 構面及び No.3 の曲げモーメントは, $M u_{j}$ まで到達せずに低下していることがわかる。また，目視により梁の 横方向の変形を確認できたことから, 横座屈が発生しているものと 判断した。また, No.1 及び 3 の最大耐力時における梁フランジ左右

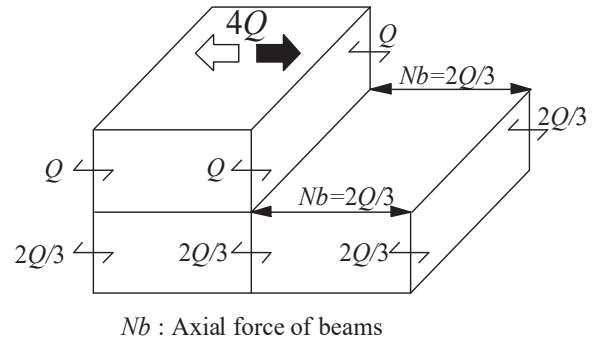

Fig.18 Axial force of beams in case of the earthquake

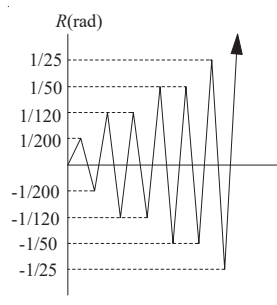

(a) No.1,2

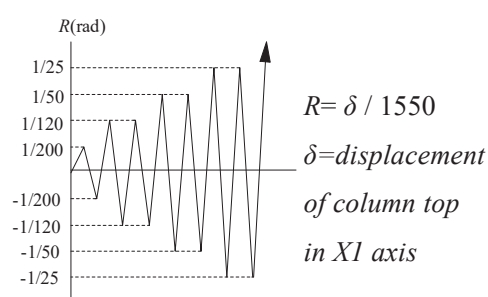

(b) No.3
Fig.19 Loading schedule

Table3 Material properties

\begin{tabular}{|c|c|c|c|c|c|c|}
\hline & \multicolumn{2}{|c|}{ member } & $\sigma_{y}$ & $\sigma_{u}$ & $\varepsilon_{u}$ & $E$ \\
\hline \multirow{4}{*}{ No.1 } & \multicolumn{2}{|c|}{ column } & 365 & 411 & 40 & $2.05 \times 10^{5}$ \\
\hline & \multirow{3}{*}{ beam } & flange & 306 & 435 & 42 & $2.07 \times 10^{5}$ \\
\hline & & web & 277 & 423 & 42 & $2.11 \times 10^{5}$ \\
\hline & & endplate & 278 & 432 & 49 & $2.10 \times 10^{5}$ \\
\hline \multirow{4}{*}{ No. 2} & \multicolumn{2}{|c|}{ column } & 364 & 440 & 41 & $1.87 \times 10^{5}$ \\
\hline & \multirow{3}{*}{ beam } & flange & 291 & 443 & 44 & $1.95 \times 10^{5}$ \\
\hline & & web & 281 & 432 & 43 & $2.02 \times 10^{5}$ \\
\hline & & endplate & 264 & 448 & 49 & $2.17 \times 10^{5}$ \\
\hline \multirow{4}{*}{ No.3 } & \multicolumn{2}{|c|}{ column } & 386 & 466 & 42 & $1.85 \times 10^{5}$ \\
\hline & \multirow{3}{*}{ beam } & flange & 321 & 452 & 40 & $2.06 \times 10^{5}$ \\
\hline & & web & 287 & 449 & 40 & $2.09 \times 10^{5}$ \\
\hline & & endplate & 263 & 427 & 40 & $2.05 \times 10^{5}$ \\
\hline \multicolumn{7}{|c|}{$\sigma_{y}:$ yield strength $\left[\mathrm{N} / \mathrm{mm}^{2}\right]$} \\
\hline \multicolumn{7}{|c|}{$\sigma_{u}:$ ultimate strength $\left[\mathrm{N} / \mathrm{mm}^{2}\right]$} \\
\hline \multicolumn{7}{|c|}{$\varepsilon_{u}:$ elongation $[\%]$} \\
\hline \multicolumn{7}{|c|}{$E$ : young's modulus $\left[\mathrm{N} / \mathrm{mm}^{2}\right]$} \\
\hline
\end{tabular}

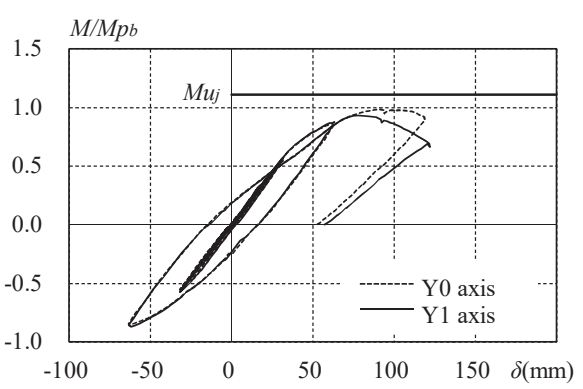

(a) No.1

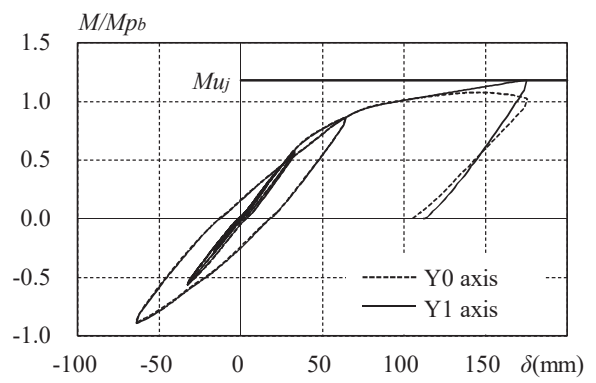

(b) No.2

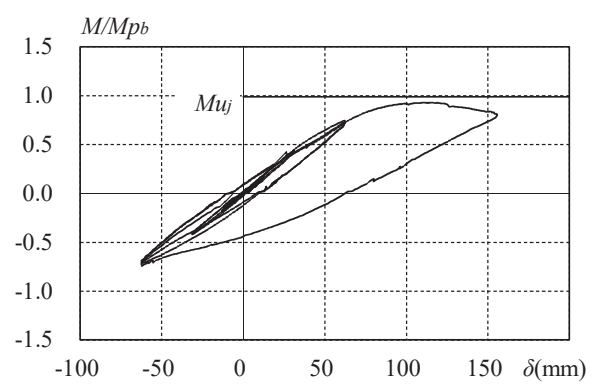

(c) No.3

Fig.20 $M-\delta$ relationship

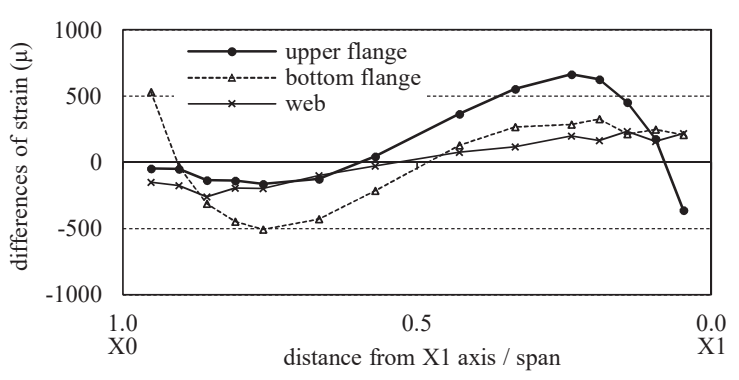

(a) No.1

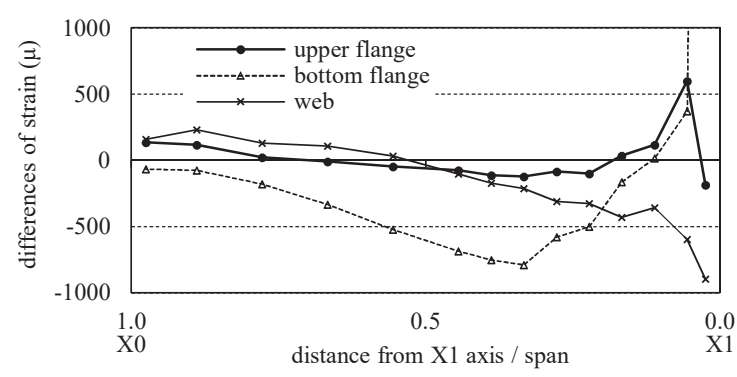

Fig.21 Strain of the beam

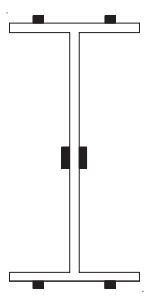

(c) Strain gauge 
及びウェブ両面のひずみの差分を Fig. 21 に示す。ひずみゲージの貼 付位置はFig.21(c)に示す位置とした。

Fig.21より, No.1のX1 軸における上フランジ（圧縮フランジ）, 及び X0 軸における下フランジ（圧縮フランジ）はひずみの差分が 大きく, 横曲げが拘束されていることがわかる。逆に X1 軸におけ る下フランジ (引張フランジ), 及び X0 軸における上フランジ（引 張フランジ） はひずみの差分が小さく, 接合部に向かってひずみが 減少傾向にある。つまり, 梁端において横曲げは固定されているが, そり変形は拘束されていないと思われる。この傾向は, No.3の X1 軸側も同じであり軸力による差異は見られない。また, No.3の X0 軸側におけるカット T による接合部では, 上下フランジともにフラ ンジのひずみの差分が小さく，横曲げが拘束されていないと思われ る。ウェブのひずみについては，4 章で考察する。

\section{2 FEM 解析によるH 形断面梁端部の境界条件の確認}

FEM 解析により得られる梁フランジに生ずる横曲げ応力から, 前述の考察通り梁端のそりが拘束されていないことを確認する。

FEM 解析に用いるプログラムは ABAQUS6.14-2 とし, No.1,2 試験体の解析モデルは Y0-Y1 スパン中央の対称面 (X-Z 面)から半分 をモデル化し, 対称面を $\mathrm{Y}$ 方向並進拘束した。No.1,2 ともに耐力が 低い軸を対象とし, No.1 は Y 1 軸, No.2 は Y 0 軸を対象と寸る。No.3 試験体は全体をモデル化した。各モデル共通で, 柱下の X 軸回り及 び Z 軸回りの回転を拘束し，柱頭には X 方向へ強制変位を与えた。 初期不整は，モード解析による最も低次のモードを与え，その他の 要素タイプ等条件は，前述の柱梁接合部解析と同じとした。

解析により得られた梁端の曲げモーメント $M$ と変位 $\delta$ の関係, 及 び最大荷重時の梁の横方向変位の実験と解析結果の比較を付録に記 載した。この結果より, 解析モデルは妥当であると考えられる。

この解析モデルの, No.1 から No.3 の梁フランジに生ずる弱軸ま わりの曲げモーメント $M f$ と変位 $\delta$ の関係を Fig.22(b)から(d)に示す。 いずれも最終サイクルの負側から正側の最大耐力までの履歴のみを 示し, エンドプレートが柱と接触する曲げモーメント $M t$ を同時に 示している。ここで, $M f$ は Fig.22(a)に示す通り, 柱フェイスより $90 \mathrm{~mm}$ 位置に並ぶ節点のX軸方向応力から上下フランジそれぞれに ついて求めている。なお, $M f$ は柱フェイスより約 $50 \mathrm{~mm}$ の位置と $90 \mathrm{~mm}$ 位置とで，ほぼ変わらないことを No.1 で確認している。 Fig.22(b)から(d)より, 何れの解析モデルも負側の最大荷重から除荷 されるに従い, 曲げモーメントの向きが上フランジと下フランジで 逆向きに移動し交差する。その後, 上下フランジに生ずる応力は正 負逆の関係で小さい值で推移寸る。これは, 梁に横方向変位が発生 しているため, 衿じれ応力が発生し, 接合部近傍でそり変形を若干 拘束し, そり応力が発生していると考えられる。梁に生ずる曲げモ ーメント $M$ が $M t$ を超えると, 離間していたエンドプレートが柱に 接触し, 压縮フランジの $M f$ が急上昇し, 引張フランジには圧縮フ ランジと同じ向きに小さい曲げモーメントが発生する。

一方，エンドプレートを柱に固着させた場合の $M f$ と変位 $\delta$ の関 係を Fig.22(e)に示す。Fig.22(e)を見ると，梁に生ずる曲げモーメン ト $M$ が小さい間は上下フランジに横曲げ応力が発生しておらず, 横 方向変位が発生していないことがわかる。 $M$ がある程度大きくなる と圧縮フランジの $M f$ は No.1 から No.3 と同じ正側に向かって上昇 するが, 引張フランジはNo.1 から No.3 と異なりほぼゼロのままか,

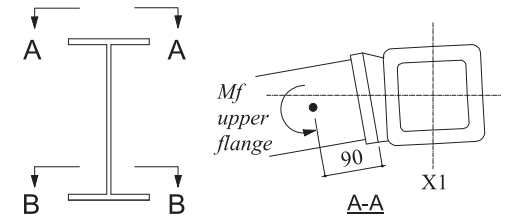

(a)

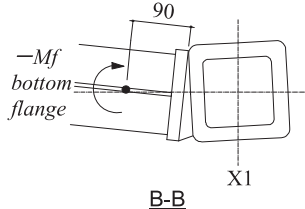

B-B

\section{0
0
0
0
0
0}

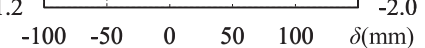

(b) No.1

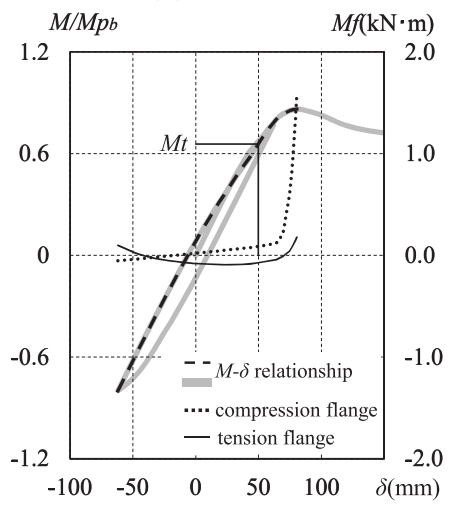

(d) No.3

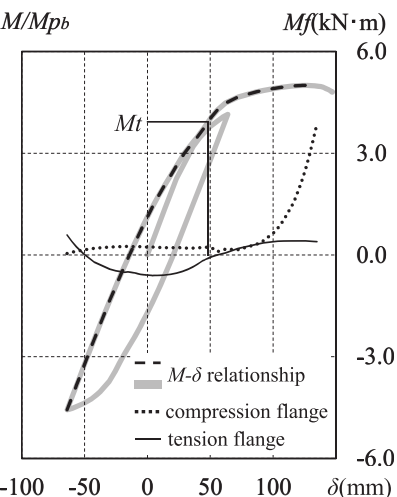

(c) No.2

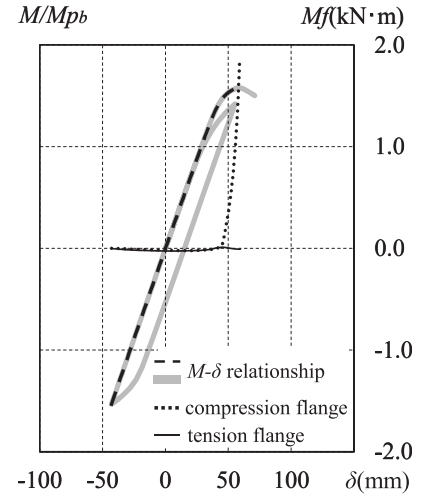

(e) No.1 (rigid connection)
Fig.22 Mf- $\delta$ relationship

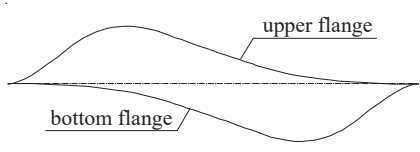

(a) Restrain tension flanges

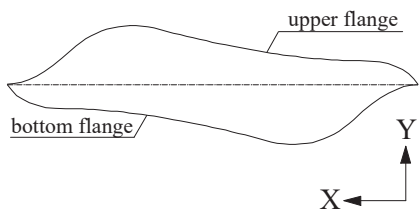

(b) Not restrain tension flanges Fig.23 Lateral displacement of flange center line

負側に小さい值を示す。ここで, Fig.23 に逆対称曲げにおける引張 フランジの横曲げ変形が拘束されている場合とされていない場合に ついて, 横座屈時の上下フランジの幅中心線の位置を実線により示 す。図中に示したX, Y 方向は, Fig.17(a)No.1 と同じである。この図 は座屈変形の概念を示したものであり, 端部境界条件による違いを 表している。接合部で引張フランジの横方向の回転が拘束されてい る場合, 接合部近傍では上下フランジは逆向きの曲率を示すことに なるが, 拘束されていない場合は同じ方向の曲率となる。このため, 引張フランジと圧縮フランジの横方向の変位差である㸚じれ変形は, 引張フランジの横方向の回転が拘束されていない方が増加する。本 解析モデルの No.1 から No.3 は引張フランジが回転したため, 接合 部近傍で引張フランジと圧縮フランジに同じ向きの曲げモーメント が発生したと考えられる。また，梁に圧縮軸力が入る No.1 と No.2 及びNo.3 を比較すると, No.1 の引張フランジに生ずる $M f$ は最大耐 
力時に正側になるものの, No.2 及び No.3 よりも小さく, 離間して いる引張側エンドプレートの横方向の回転は小さいと考えられる。 これには, 梁の圧縮軸力によりエンドプレートの離間量が小さくな ることが理由として考えられる。

以上, 実験によるひずみゲージの值, 及び FEM 解析結果より, エンドプレートが柱から離間している場合, フランジの横曲げ拘束 度が小さい。そのため, 梁端部の境界条件は, 梁に生ずる軸力に関 わらず, エンドプレートが面外に塑性変形した後, 圧縮, 引張フラ ンジ側ともに柱から離間している状態では, そり及び弱軸曲げとも に拘束なしの単純支持とし, 片側が柱に接触している状態では, そ り自由, 弱軸曲げ固定と扱う必要があると考えられる。

\section{4. 境界条件と横座屈耐力の推定方法}

ここまで得られた知見をもとに，フラッシュ形エンドプレートに より接合される $\mathrm{H}$ 形断面梁の横座屈耐力の推定方法を提案する。ま ず両側離間の横座屈耐力を $M c 1$ とし, 片側離間の横座屈耐力を $M c 2$ とする。両側離間の状態で梁に生ずる曲げモーメントが $M c 1$ に達す ると, $M c 1$ で梁は横座屈する。両側離間の曲げモーメントは, 各サ イクルにおける最大曲げモーメント $M_{\text {peak }}$ に対して, 反対向きの曲げ モーメントが Fig.16により求まる $M t$ 以下の時である。ここで, $M_{\text {peak }}$ は片側離間の横座屈耐力 $M c 2$ 以下であるはずなので, Fig. 16 の横軸 を $M c 2$ として, 斜めの直線の縦軸の值が両側離間の状態における曲 げモーメントの上限值である。この上限值よりも $M c 1$ が小さければ, 両側離間の状態で横座屈し, 逆に大きければ, 片側離間の状態で横 座屈する。さらに, $M c 1$ が $\alpha M u_{j}$ より大きく, かつ $M c 2$ が $M u_{j}$ より 大きい場合, 横座屈をしないと言える。これら横座屈耐力 $M c 1, M c 2$ と, 接合部の各種耐力 $M y_{j}, M u_{j}$ により特定される横座屈に対する境 界条件と横座屈発生の有無は, Fig.24のように表すことができる。 設計対象の梁が Fig. 24 の領域 A から C のうちどの領域に該当するか 調べることにより，横座屈耐力を推定することができる。

\section{1 H 形断面梁の横座屈耐力の推定方法}

I . 各種曲げ耐力の算出

(1) 設計対象のフラッシュ形エンドプレート接合の初期降伏耐力 $M y_{j}$, 最大耐力 $M u_{j}$ 及び $\alpha$ を求める。

(2) 当該接合部を有する $\mathrm{H}$ 形断面梁の全塑性耐力 $M p_{b}$ を求める。

(3) 当該梁の弾性横座屈耐力について, 当該フラッシュ形エンドプ レートを単純支持として扱った $M_{e} 1$, 横曲げ固定そり自由とし て扱った $M_{e} 2$ それぞれを，文献 7)の方法により求める。

(4) 当該弾性横座屈耐力に対応した横座屈限界耐力 $M c 1, M c 2$ を, 文献 9)及び 10)の方法により求める。

II . 境界条件の設定と最大耐力

I で求めた各種耐力を $x=M c 2 / M u_{j}, y=M c 1 / M u_{j}$ として Fig.24 上に プロットする。

(1) プロットが領域 A となる場合は, $M c 1$ を最大耐力とする。

(2) プロットが領域 B となる場合は, $M c 2$ を最大耐力とする。

(3) プロットが領域 $\mathrm{C}$ となる場合は，Muj 最大耐力とする。

計算式により表現すると式(3.1)から(3.3)となる。

領域 $\mathrm{A}: M c 1 \leqq \alpha M u_{j}\left(M c 2-M y_{j}\right) /\left(M u_{j}-M y_{j}\right)$

$$
\text { かつ } M c 1 \leqq \alpha M u_{j}
$$

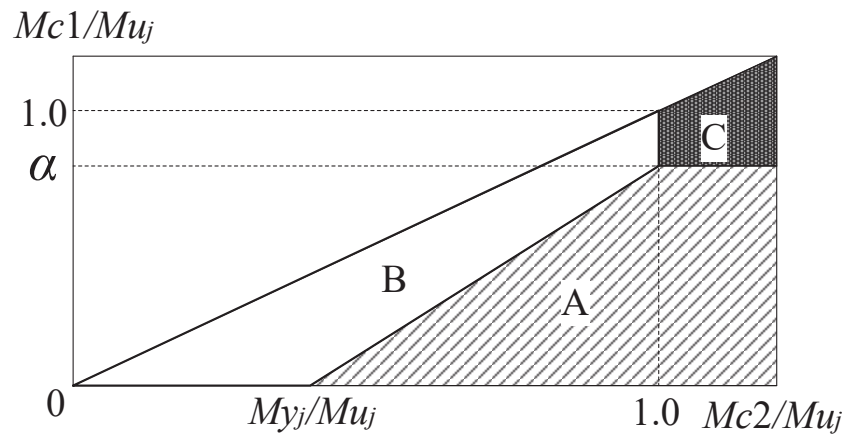

Fig.24 Boundary conditions of beams

Table4 Effective length factors

\begin{tabular}{|c|c|c|c|c|}
\hline & \multicolumn{2}{|c|}{ Boundary condition } & \multirow{2}{*}{$k_{u}$} & \multirow{2}{*}{$k_{\beta}$} \\
\cline { 2 - 3 } & Left & Right & & \\
\hline No.1 and 2 & Lateral & Lateral & 0.5 & 1.0 \\
\hline No.3 & Warping & Lateral & 0.668 & 0.654 \\
\hline
\end{tabular}

Table5 Moment strength

\begin{tabular}{|c|c|c|c|c|c|c|c|}
\hline & $M y_{j}$ & $M u_{j}$ & $M c 1$ & $M c 2$ & $\alpha$ & $\begin{array}{c}\text { Boundary } \\
\text { area }\end{array}$ & $e M_{\max }$ \\
\hline No.1 & 40 & 120 & 73 & 84 & 0.80 & $\mathrm{~B}$ & 98 \\
\hline No.2 & 40 & 117 & 86 & 102 & 0.80 & $\mathrm{~B}$ & 109 \\
\hline No.3 & 38 & 103 & 74 & 94 & 0.80 & $\mathrm{~B}$ & 98 \\
\hline
\end{tabular}

領域 B : $M c 1>\alpha M u_{j}\left(M c 2-M y_{j}\right) /\left(M u_{j}-M y_{j}\right)$

$$
\text { かつ } M c 2 \leqq M u_{j}
$$

領域 $\mathrm{C}: M c 1>\alpha M u_{j}$ かつ $M c 2>M u_{j}$

次に, 文献 7)による各種境界条件に対する弾性横座屈耐力の算出 方法を，基本式(3.4)とともに次に示す。

$$
M_{e}=C_{1} \frac{\pi^{2} E I_{y}}{\left(k_{u} l\right)^{2}} \sqrt{\frac{I_{\omega}}{I_{y}}\left\{\left(\frac{k_{u}}{k_{\beta}}\right)^{2}+\frac{G J\left(k_{u} l\right)^{2}}{\pi^{2} E I_{\omega}}\right\}}
$$

ここで， $M_{e}$ は弾性横座屈耐力, l梁長さ, Eはヤング率, $G$ はせん 断弾性係数, $I_{y}$ は弱軸まわりの梁断面 2 次モーメント, $I_{\omega}$ は曲げね じり定数, $J$ は亦じり定数, $k_{u}$ は弱軸曲げに対する座屈長さ係数, $k_{\beta}$ は曲げねじりに対する座屈長さ係数, $C_{1}$ はモーメント修正係数であ る。

本論では, そり自由, 横曲げ固定の座屈長さ係数が, 文献 7)に示 されている各種境界条件に対する座屈長さ係数提案值を参考にして 定めることができるとする。以下に，No.1～3 試験体の当該座屈長 さ係数の定め方を示す。

始めに, No.1, 2 試験体の座屈長さ係数を定める。境界条件は, 両端そり自由, 横曲げ固定であるとする。文献 7) では両端固定支持 の場合, $k_{u}=0.5, k_{\beta}=0.5$ としている。一方, 両端単純支持の場合は, $k_{u}=1.0, k_{\beta}=1.0$ としている。両端そり自由, 横曲げ固定の場合, 両 端固定支持の $k_{\beta}$ が単純支持の $k_{\beta}$ になるとして, $k_{u}=0.5, k_{\beta}=1.0$ とす る。次に, No. 3 試験体の座屈長さ係数を定める。境界条件は, 左端 そり固定, 右端がそり自由横曲げ固定であるとする。文献 7) では左 端そり拘束一右端固定支持の場合は, $k_{u}=0.668, k_{\beta}=0.465$ としてい る。一方, 左端そり拘束一右端単純支持の場合は, $k_{u}=0.967, k_{\beta}=0.654$ としている。左端そり固定, 右端そり自由横曲げ固定の場合, 左端 
そり拘束一右端固定支持の $k_{\beta}$ が，左端そり拘束一右端単純支持の $k_{\beta}$ になるとして $, k_{u}=0.668, k_{\beta}=0.654$ とする。定めた座屈長さ係数を Table4 に示す。

圧縮軸力が発生する場合は, 文献 10)に示される曲げねじれ座屈 の最大耐力の算出式(3.5)における $M_{c r}$ に, 文献 9 ) による横座屈耐力 $M c 1$ 及び $M c 2$ を代入し, 得られた $M_{1}$ を $M c 1$ 及び $M c 2$ とする。

$$
\frac{N}{N_{c r y}}+\frac{C_{M} \cdot M_{1}}{\left(1-\frac{N}{N_{E}}\right) \cdot M_{c r}}=1.0
$$

ここで, $N$ は圧縮軸力, $N_{c r y}$ は弱軸まわりの座屈強度（座屈長さ $=0.5 L), \quad C_{M}$ は等価曲げモーメント修正係数 $(=1.0), M_{1}$ は最大曲げ 耐力, $N_{E}$ は弾性座屈強度 (座屈長さ $=0.5 L$ ) , $M_{c r}$ は圧縮軸力が存在し ない場合の横座屈強度である。今回の実験による最大耐力を, 以上 の推定方法に従い求めると Table5 の $M c 2$ となる。いずれの試験体も $M c 2$ は，実験結果 ${ }_{e} M_{\text {max }}$ を安全側に評価している。

\section{2 FEM 解析による推定方法の妥当性の確認}

前述の推定方法の妥当性を FEM 解析により確認する。解析モデ ルは, 前述の No.1(model.1-1)に対し, 条件を変化させた Table6 に 示す合計 7 モデルとする。変化させる条件は，(1)梁端を柱に完全固 定した場合, (2)柱が剛体の場合と柱が剛体かつ梁端を柱に固定した 場合, (3)梁に生ずる軸力が引張の場合, (4) Fig.24 の領域 C に分類 される梁の場合の合計 5 つとする。得られた曲げモーメント $M$ と載 荷点の変位 $\delta$ の関係を Fig. 25 に示す。

(1)梁端を柱に完全固定した場合

Fig.25(a)より，梁端を柱に完全固定した model.1-2 は, model.1-1 よりも耐力が若干上昇した。また, Fig.26に, Fig.21 と同様ウェブ の両面のひずみ（対数ひずみ）の差分と，材軸方向位置の関係につ いて, 最大荷重までの変化を示す。Fig.26に示す通り, model.1-1 は座屈の面外変形の初期段階において接合部近傍でひずみの差分が 生じ, model.1-2 では生じていない。梁端のウェブのひずみ差は Fig.21 に示寸実験結果も同じ傾向が見られた。これは, Fig.26 左図 に示すようにそり変形した場合, 梁端ウェブがフランジ間で若干曲 がることが原因と考えている。つまり, そり拘束度が弱いと, ウェ ブのひずみの差分が端部で大きくなる。これが，完全固定とフラッ シュ形エンドプレートの横座屈耐力の差異の原因と考えると, フラ ッシュ形エンドプレート接合形式による $\mathrm{H}$ 形断面梁の境界条件は, 単純支持又は横曲げ固定そり自由として扱う必要がある。

(2)柱が剛体の場合と，柱が剛体かつ梁端を柱に固定した場合

Fig.25(b)より, 柱を剛体として扱い十分大きな弾性係数を持つ弾 性体とした model.1-3 と, 実験による材料特性を与えた model.1-1 の間には, 耐力に有意な差がなかった。さらに, Fig.25(c)より, 接 合部を柱に固定しても柱の素材特性による差異は見られなかった。 つまり, 本解析において, 柱のねじれ変形は座屈耐力に影響を与え ていない。

(3)梁に生ずる軸力が引張りの場合

Fig.25(d)より, 梁に引張り軸力が生じた状態で座屈するように, 最終加力でジャッキにより柱頭を引いた model.1-5 と, 圧縮軸力が 生じた状態で座屈させた model.1-1の間には, 耐力に有意な差が見 られた。なお, 両モデルの初期不整は, それぞれのモード解析によ る最も低次のモードに, 同じ倍率を乗じて与えた。本解析において,
Table6 Analysis model

\begin{tabular}{|c|c|c|c|c|}
\hline No & $\begin{array}{c}\text { Flush end plates } \\
\text { on column }\end{array}$ & $\begin{array}{c}\text { Column } \\
\text { material }\end{array}$ & Axial force & $\begin{array}{c}\text { Boundary } \\
\text { area }\end{array}$ \\
\hline $1-1$ & not fixed & \multirow{2}{*}{ not rigid } & \multirow{4}{*}{ compression } & \multirow{5}{*}{ B } \\
\hline $1-2$ & fixed & & & \\
\hline $1-3$ & not fixed & \multirow{2}{*}{ rigid } & & \\
\hline $1-4$ & fixed & & & \\
\hline $1-5$ & \multirow{3}{*}{ not fixed } & not rigid & tension & \\
\hline $1-6$ & & rigid & \multirow{2}{*}{ compression } & $\mathrm{A}$ \\
\hline $1-7$ & & not rigid & & $\mathrm{C}$ \\
\hline
\end{tabular}

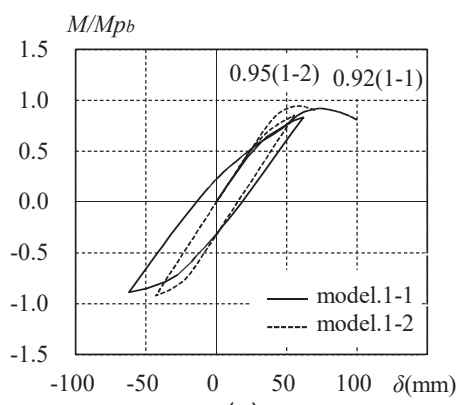

(a)

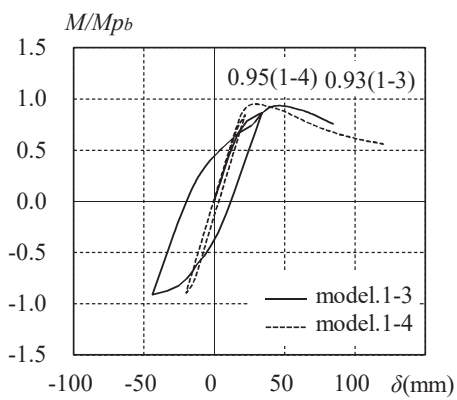

(c)

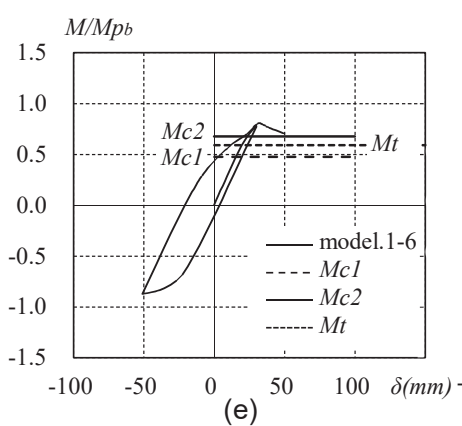

Fig. $25 M-\delta, M-\theta_{b}$ relationship

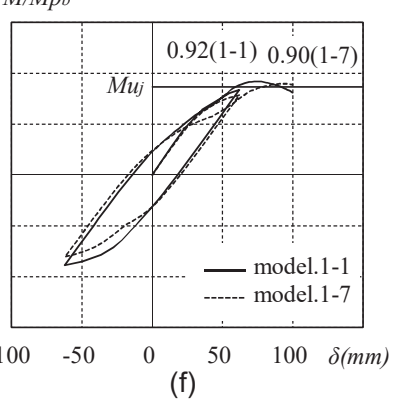

(f)

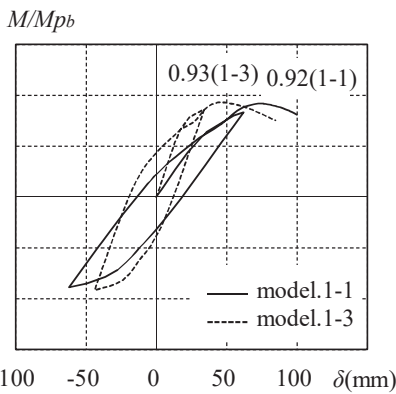

(b)

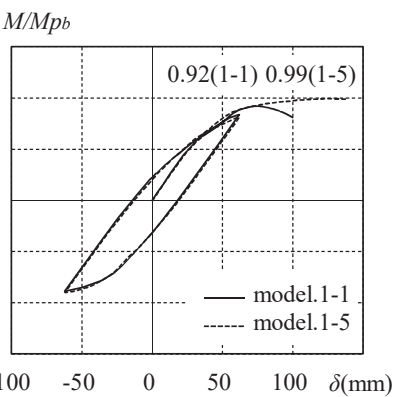

(d)
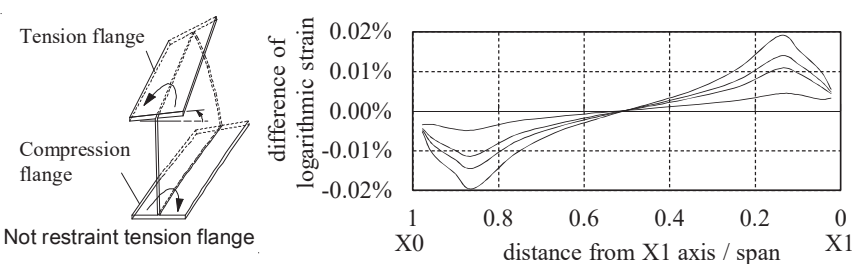

(a) model. 1-1
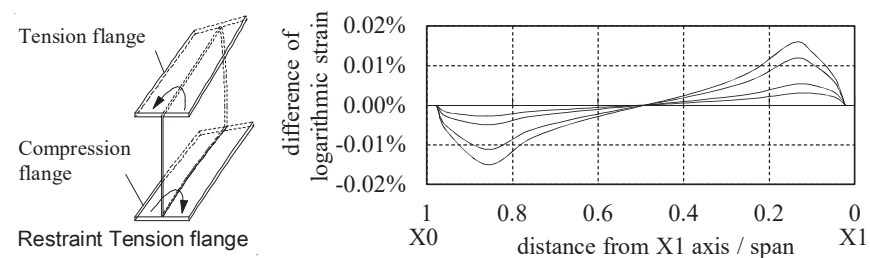

(b) model. 1-2

Fig.26 Difference of web surfaces strain 
梁に生ずる軸力が横座屈耐力に影響を与えていることがわかった。 ここで, 軸力と等曲げモーメントを受ける梁の横座屈耐力の評価方 法が文献 11)により提案されている。今回は逆対称曲げであるため, 座屈耐力は前述の式(3.5)により安全側の評価が可能であることを示 した。今後は, 地震時に梁に生ずる軸力の変動履歴, 及び軸力と塑 性変形能力の関係について検討したい。

(4)Fig.24の領域 A に分類される梁の場合

Fig.25(e)より, 領域 A でも座屈耐力 $M c 2$ を上回った。圧縮側フラ ンジ側のエンドプレートが柱に接触してから座屈した。提案してい る推定方法は少し安全側すぎる可能性がある。なお, model.1-6 は 圧縮軸力を考慮した式(3.5)により $M c 1$ 及び $M c 2$ を算出すると領域 B に分類されるが, 領域 A と同じ条件となるように, 梁に生ずる引張 り軸力により座屈耐力が高くなることを利用して, 負側でエンドプ レートを大きく離間させ，正側で圧縮フランジ側のエンドプレート が離間している状態で単純支持の Mc1 を超えるようにした。

\section{(5)Fig.24の領域 C に分類される梁の場合}

接合部の最大耐力 $M u_{j}$ が, model.1-1 の解析による座屈耐力以下 となるようにエンドプレートの厚みを $12 \mathrm{~mm}$ に変更した model.1-7 の $M-\delta$ 関係を Fig.25(f)に示す。Fig.25(f)より, model.1-7 は接合部 の最大耐力の推定值 $M u_{j}$ まで座屈せず, 耐力低下が生じなかった。

以上, 推定方法の妥当性を確認した結果, 領域 $\mathrm{B}$ 及び $\mathrm{C}$ に対し, 妥当であり, 領域 $\mathrm{A}$ に対しては安全側過ぎる推定方法となっている 可能性がある。しかし, 確認した解析モデルが少ないため, より詳 細な検討は今後の課題としたい。また、ウェブ設備孔がない場合で も, 同様の結果が得られるかどうかの検討は, 今後の課題としたい。

\section{5. まとめ}

フラッシュ形エンドプレートにより接合される $\mathrm{H}$ 形断面梁の横 座屈耐力について, 接合部の実験により, 接合部の最大耐力は, 式 (2.4)により推定でき, エンドプレートの離間状態は, Fig.16により 予測できることを示した。また, エンドプレートと H 形断面梁の復 元力特性は分離して扱うことが可能で, $\mathrm{H}$ 形断面梁の復元力特性は 柱に完全に固定した場合と同じ性状を示寸ことがわかった。

続いて横座屈実験による接合部近傍の梁フランジのひずみ分布及 び FEM 解析による横曲げ応力から, 梁端部の境界条件は, 梁の軸 力の影響なく, エンドプレートが面外に塑性変形した後, 圧縮, 引 張フランジ側ともに柱から離間している状態では, そり及び弱軸曲 げともに拘束なしの単純支持とし, 片側が柱に接触している状態で は, そり自由-弱軸曲げ固定と扱う必要があることがわかった。そし て, 接合部の耐力と横座屈耐力より特定される横座屈に対する境界 条件と横座屈発生の有無を Fig. 24 に示すとともに, Fig.24 を用いた 本接合形式を有する $\mathrm{H}$ 形断面梁の横座屈耐力の推定方法を示した。

\section{References}

1) Recommendation for Design of Connections in Steel Structures, AIJ, 2012

2) Ben KATO, Hiroshi SAKUMA, Akiyoshi MUKAI: Maximum strength of bolted beam-to-column moment connection, Construction Engineering, AIJ, vol. 35B, 1989. 3

3) Takeshi NISHIMAKI, Daikou ITIOKA, Yasuhiro OHTANI: Effect of local behavior on rotational stiffness of semi-rigid connection with flush endplate, Summaries of Technical Papers of Annual Meeting, Architectural Institute of Japan, C-I, pp. 629-630, 2006
4) Naoshi KUBO, Yoshinobu TANUMA, Kenichi HASHIMOTO: Cyclic Behaviors of Beam-to-Column Flush End Plate Connections, Summaries of Technical Papers of Annual Meeting, Architectural Institute of Japan, C-I, pp. 443-444, 1998

5) Kenichi OHI, Seung-Jae LEE, Yuske SHIMAWAKI, Ruben GUZMAN: Hysteretic Behaviors of End-plate Connections Subjected to Earthquake Loading and Improvement on their Rotation Capacities, The Report of Institute of Industrial Science of The University of Tokyo, vol. 52-2, 2000. 2

6) Design of Joints in Steel and Composite Structures, ECCS 2016

7) Kikuo IKARASHI, Nobuyuki TOMO, Tao WANG: Effects of boundary conditions and end moment ratio on elastic lateral buckling strength of $\mathrm{H}$-Shaped beams, Journal of Structural and Construction Engineering (Transactions of AJJ), Vol. 76, No. 670, pp. 2173-2181, 2011. 12 (in Japanese)

8) Kikuo IKARASHI, Ryota SUEKUNI, Nobuyuki TOMO: Coupled buckling behavior and plastic deformation capacity of $\mathrm{H}$-Shaped steel beams under cyclic bending shear, Journal of Structural and Construction Engineering (Transactions of AIJ), Vol. 77, No. 678, pp. 1319-1328, 2012. 8 (in Japanese)

9) Recommendation for Limit State Design of Steel Structures,AIJ, 2010

10) Recommendations for the Plastic Design of Steel Structures, AIJ, 2010

11) Yoshihiro KIMURA, Takeshi MATSUO and Yuki YOSHINO: Estimation of elasto-plastic lateral buckling stress for $\mathrm{H}$-shaped beams with lateral-rotational braces on subjected to axial force and flexural moment, Journal of Structural and Construction Engineering (Transactions of AIJ), Vol. 79, No. 703, pp. 1299-1308, 2014. 9 (in Japanese)

\section{Appendix}

本論文で実施した実験と解析結果の比較を Fig.A1 と A2 に示す。Fig.A1 は $M-\delta$ 関係, Fig.A2 は最大荷重時の梁の横方向変位を示している。 $M-\delta$ 関係で は, 実験結果より解析結果の方が耐力に対する変形は小さくなっており, 最 大耐力は実験よりも若干小さいが, 最大荷重時の梁の横方向変位の形状は, 実験結果と良い対応を示しており, 解析モデルは妥当と判断した。

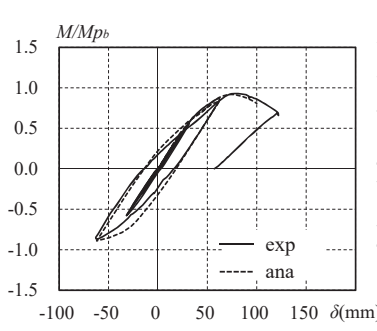

(a) No.1(model.1-1)

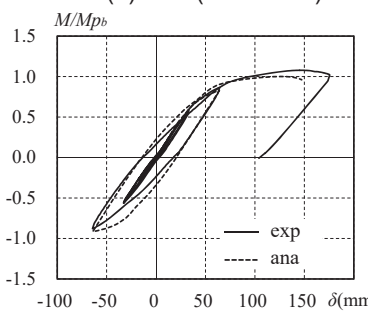

(b) No.2(model.2)

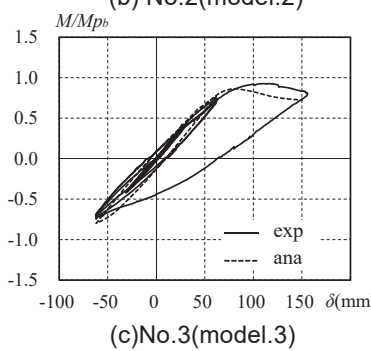

Fig.A1 $M-\delta$ relationship

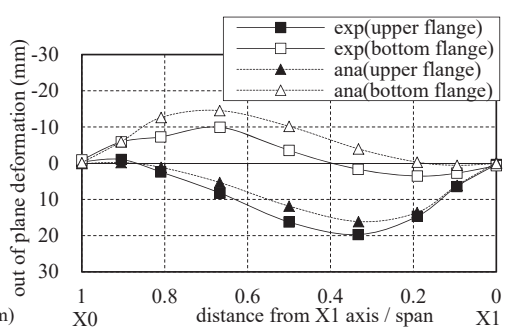

(a) No.1(model.1-1)

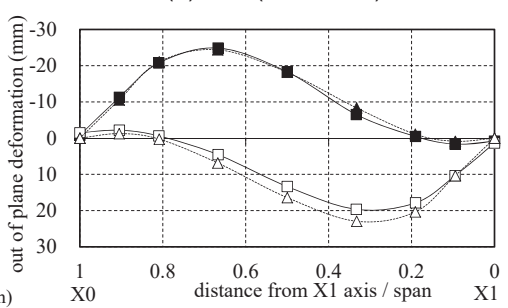

(b) No.2(model.2)

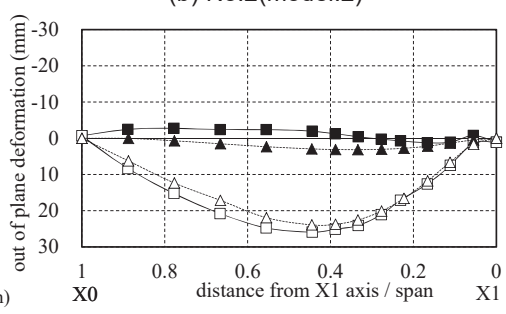

(c) No.3(model.3)

Fig.A2 Lateral displacement at the ${ }_{\mathrm{e}} \mathrm{M}_{\max }$ 


\title{
FAILURES AND PREDICTION METHODS OF LATERAL BUCKLING STRENGTH OF H-SHAPED BEAMS CONNECTED BY FLUSH END PLATES
}

\author{
Hiroshi MATSUBARA* , Junichi TAKAHASHI**, Yoshiharu IKEGUCHI*** \\ and Kikuo IKARASHI*** \\ * Asahi Kasei Homes Corporation, M. Eng. \\ ** Asahi Kasei Corporation, Corporate Production Technology, Production Technology Center, Computer Aided Engineering Dept., Dr. Eng. \\ *** Asahi Kasei Homes Corporation, Dr. Eng. \\ **** Assoc. Prof., Dept. of Arch. and Build. Eng., Tokyo Institute of Technology, Dr. Eng.
}

The flush end plates connections have been researched in several countries. For example, in Japan, Kato, Sakuma and Mukai have presented the prediction method of ultimate moment strength of the connection, and in Europe, ECCS(2016) has presented the moment resistant and stiffness evaluation, and classification criteria for the rotational ductility. In addition there are numerous studies of the lateral buckling of $\mathrm{H}$-shaped beams. For example, Ikarashi,Tomo and Wang(2011) have presented the effects of boundary condition and moment ratio on elastic lateral buckling strength of $\mathrm{H}$-shaped beams.

This paper presents a method to predict the ultimate strength of the $\mathrm{H}$-shaped beams connected by flush end plates which fall into the lateral buckling or the connection failures. The method is based on the determination of the two boundary conditions due to yielding of flush end plates.

The study is conducted by the following procedure: First, the behavior of the connection is researched by the no buckling experiment under the cyclic loading. As a result, it is found that the moment strength which cause the plastic deformations of the endplates and which contacts the deformed endplates on the surface of column can be predicted. In addition the non-linear FEM analysis is conducted to compare the moment-rotation relationship of the beams connected by flush endplates with those of the beams connected rigidly. As a result, they are similar. It means that lateral buckling strength can be predicted by the method based on the study of rigid connections. Next, the behaviors of the lateral buckling of the beams are researched by the buckling experiments under the cyclic loading, and then the boundary conditions of the beams are estimated by strain gauges put on the flanges. In addition the FEM analysis is conducted to estimate the boundary conditions of the beams from the lateral moment in flanges. As a result, it is found that the lateral moment is small in tension flange near the connection, so that the connection is not restraining warping of the end of the beam. We recommend that the boundary conditions of the beams connected by flush end plates are simple support or lateral bending support. The lateral buckling strengths under the two boundary conditions determine that which strength must be applied. Final, the several effects of factors are researched.

Findings of this study can be summarized as follows:

(1)The ultimate moment strength of the flush end plate connection is predicted by Eq. 2.4. In addition the moment-rotation relationship removed the effect of end plate deformation is similar to those of beams connected rigidly.

(2) The lateral buckling strength of $\mathrm{H}$-shaped beam connected by flush endplate can be predicted by determination of boundary conditions determined from Fig. 24.

(3)The axial force is effective for the buckling strength, which was already studied by Kimura, Matsuo and Yoshino(2014). This study finds that boundary conditions are not influenced by the axial force. Moment strengths calculated by Eq. 3.4, and Recommendation for Limit State Design of Steel Structures and Eq. 3.5 suggested by Recommendations for the Plastic Design of Steel Structures are smaller than those of the experimental results. 